prevents major neurological impairment in most PKU children.

Thus, on the basis of clinical experience to date, it is uncertain whether treating women who have PKU with a low phenylalanine diet during pregnancy lessens the harmful effects of phenylketonuria on the fetus. However, there are grounds for believing that such treatment may be beneficial, especially if started before conception.

The pilot study which led to the detection of this case was designed by Professor J Farquhar, Department of Child Life and Health, Edinburgh University, in collaboration with Dr J S Stevenson, Consultant Bacteriologist, Stobhill General Hospital. We thank Mr Robert Kennedy for doing the Guthrie tests, Dr M L McDonald for the Griffiths's test, Mr J De Courcy for the Weschler intelligence quotient, and Miss C M Fleming for advising on the diet.

\section{References}

1 Frankenburg W K, Duncan B R, Coffelt R W, Koch R, Coldwell J G, Son C D. Maternal phenylketonuria. Implications for growth and development. J Pediatr 1968; 73: 560-70.

2 Gairdner D, Pearson J. A growth chart for premature and other infants. Arch Dis Child 1971; 46: 783-7.

3 Allan J D, Brown J K. Maternal phenylketonuria and fetal brain damage- an attempt at prevention by dietary control. In: Holt K S, Coffey V P, eds. Some recent advances in inborn errors of metabolism. Edinburgh: Livingstone, 1968: 14-36.

- Bouvierre-Lapierre M, Saint-Dizier C, Freycon F, David $M$, Dorche $C$, Jeune $M$. Deux infants nés de mère phénylcétonurique. Échec d'un régime pauvre en phenylalanine institue pendant la deuxieme grossesse. Pediatrie 1974; 29 : 51-72.

5 Bush R T, Dukes P C. Progeny, pregnancy, and phenylketonuria. NZ Med J 1975; 82: 226-9.

- Smith I, Macartney F J, Erdohazi M, et al. Fetal damase despite low-phenylalanine diet after conception in a phenylketonuric woman. Lancet $1979 ;$ i: 17-9.

7 Farquhar J W. Baby of a phenylketonuric mother. Inferences drawn from a single case. Arch Dis Child 1974; 49: 205-8.

Correspondence to $\mathrm{Dr} \mathbf{T}$ M Scott, Division of Medical Paediatrics, Stobhill General Hospital, Springburn, Glasgow G21 3UW.

\section{Commentary}

\section{J W FARQUHAR}

\section{Department of Child Life and Health, University of Edinburgh}

Successfully treated PKU girls are reaching childbearing age. The number will grow even faster as those who were diagnosed by the Guthrie test reach maturity. Many have already stopped the diet. Most are eligible for marriage and some may believe that they will have normal children if they return to diet before or during pregnancy. Early experience of such dietary manipulation must make us pause and consider. It ranges in Britain from some reassuring success to rather more disturbing failure without suggesting a clear reason for the difference. The above case falls into the unsuccessful group and even in the recent series from Manchester, ${ }^{1}$ success, although impressive at an early stage in developmental testing, is not perfect. Buist et al. in Oregon ${ }^{2}$ similarly have had mixed fortunes with a small group in whom the maternal serum phenylalanine was controlled from 8 to 30 weeks of gestation.

A worldwide review of phenylketonuric pregnancies was presented by Lenke and Levy ${ }^{3}$ at a meeting of the American Society of Human Genetics. In untreated pregnancies, in which the maternal serum phenylalanine level exceeded $1.2 \mathrm{mmol} / \mathrm{l}$, microcephaly and mental retardation occurred in $90 \%$. When the maternal level lay between 0.96 and $1.2 \mathrm{mmol} / 1$ they were found in $75 \%$ of children. Congenital heart disease was also present in many. It was concluded that treatment started after conception but before the 20th gestational week prevented microcephaly but not congenital heart disease. Recently Nielsen et al. ${ }^{4}$ reported the birth of an apparently normal baby to a relatively mild phenylketonuric woman whose blood phenylalanine level was held in an acceptable range $(0.48$ to 0.61 $\mathrm{mmol} / \mathrm{l}$ ) before conception and in the range $0 \cdot 18$ to $0.48 \mathrm{mmol} / 1$ from conception to delivery.

So far no absolutely consistent relationship has emerged between outcome and maternal serum phenylalanine level (or urinary phenylketones) at conception or later, the week of pregnancy at which control was achieved, age, or maternal intelligence. Future studies must ensure that there are no other fetal insults in each pregnancy. They will need to identify, if possible, the defect in maternal phenylalanine metabolism (including the rare biopterin deficiency). They will need to document phenylalanine levels during the prenatal weeks and throughout pregnancy and to record levels below $0.12 \mathrm{mmol} / 1$ as carefully as those above $0.6 \mathrm{mmol} / 1$. Those with expertise in transplacental nutrition should examine the possibility that the low phenylalanine diet may impair fetal growth and development. Aborted fetuses should not be discarded without careful examination. It seems unlikely that poor PKU control in childhood and adolescence could by itself be mutagenic. Experience may now grow quickly and must be shared. The wiser PKU women may prefer to delay child bearing for a few more years until better informed advice can be given. The recent discovery ${ }^{5}$ that phenylalanine ammonia lyase (or PAL) may enable a PKU woman to eat a relatively normal diet while maintaining normal blood phenylalanine levels could greatly facilitate prepregnancy and pregnancy control. 
References

1 Komrower G M, Sardharwalla I B, Coutts J M J, Ingham $D$. Management of maternal phenylketonuria : an emerging clinical problem. Br Med J 1979; i: 1383-7.

2 Buist N R M, Lis E W, Tuerck J M, Murphey W H. Letter: Maternal phenylketonuria. Lancet 1979; ii: 589.

3 Lenke R R, Levy H L. International survey of maternal phenylketonuria and hyperphenylalaninaemia. $N$ Engl $J$ Med 1980; in press.

4 Nielsen K B, Wamberg E, Weber J. Letter: Successful outcome of pregnancy in a phenylketonuric woman after low-phenylalanine diet introduced before conception. Lancet 1979; i: 1245.

5 Anonymous. Dietary promise for PKU patients. Medical Research Council News 1980; No. 8, 3.

\title{
Biopterin defect in a normal-appearing child affected by a transient phenylketonuria
}

\author{
FRANCOISE REY, ROBERT J LEEMING, JOHN A BLAIR, AND JEAN REY \\ Unité de Recherches de Génétique Médicale (INSERM), Hôpital des Enfants Malades, Paris, France, \\ and General Hospital, Birmingham
}

SUMMARY A child diagnosed as having transient phenylketonuria was found to have reduced synthesis of tetrahydrobiopterin and an abnormal clearance of phenylalanine, but he remained clinically normal when on a normal diet. A small amount of 7,8-dihydrobiopterin was found in his serum; this distinguishes the case from that of malignant hyperphenylalaninaemia.

A defect in biopterin metabolism has been found in a few patients with hyperphenylalaninaemia although their hydroxylase and reductase activities have been normal. ${ }^{1-4}$ In two of these patients the serum biopterin concentration, as assayed by Crithidia fasciculata, did not rise after an oral or an intravenous phenylalanine load as it does in normal subjects and in those with the usual variants of phenylketonuria (PKU), and in patients affected by dihydropteridine reductase deficiency. ${ }^{5-7}$ The mechanism of the biopterin response to the rise of plasma phenylalanine level is unclear, but this characteristic distinguishes without liver biopsy, among the new variants with progressive neurological illness, ${ }^{8}$ those who are affected by dihydropteridine reductase deficiency and those suffering from a defect in biopterin synthesis. ${ }^{5}$ We now report a case of so-called transient $\mathrm{PKU}^{9}$ in which a low biopterin serum level and an atypical zero-order kinetics of phenylalanine disappearance were present at 5 years of age in a seemingly normal child.

\section{Methods and results}

This boy was born on 9 December 1973, and was the second child of healthy unrelated parents. Birthweight was $3.82 \mathrm{~kg}$. At 5 days a Guthrie test showed a serum phenylalanine level of $0.6 \mathrm{mmol} / 1$ (10 $\mathrm{mg} / 100 \mathrm{ml}$ ). The infant was bottle fed with dried cows' milk formula (protein intake $6 \mathrm{~g} / \mathrm{kg}$ per day) and one month later the phenylalanine plasma level was $3.5 \mathrm{mmol} / 1(58 \mathrm{mg} / 100 \mathrm{ml})$, but with a protein intake of $3 \mathrm{~g} / \mathrm{kg}$ per day (adapted formula) it returned within 4 days to $1.1 \mathrm{mmol} / 1(18 \cdot 2 \mathrm{mg} / 100$ $\mathrm{ml}$ ) (tyrosine $0.72 \mathrm{mg} / 100 \mathrm{ml}(0.04 \mathrm{mmol} / \mathrm{l})$ ). A low phenylalanine diet (Lofenalac) was started on the 36th day of life. It was possible rapidly to increase the phenylalanine intake from 300 to $450 \mathrm{mg} /$ day and at 6 months, when a normal diet was reintroduced, the phenylalanine level remained below $0 \cdot 2 \mathrm{mmol} / 1(3 \cdot 3$ $\mathrm{mg} / 100 \mathrm{ml}$ ). Lofenalac was stopped and until he was 1 year old he received a restricted natural protein diet $(2 \cdot 5 \mathrm{~g} / \mathrm{kg})$. Subsequently a regular diet was instituted and since then the phenylalanine plasma level, measured by fluorimetry, has not exceeded $0 \cdot 2$ $\mathrm{mmol} / \mathrm{l}$. The physical and intellectual development have been normal: at 5 years IQ is 108 .

An intravenous phenylalanine load was performed at age 1 year; the plasma concentration returned from $2 \cdot 7 \mathrm{mmol} / 1(44 \cdot 6 \mathrm{mg} / 100 \mathrm{ml})$ to normal values within 2 days, after a very slow and atypical kinetics of disappearance; phenylpyruvic acid and o-hydroxyphenylacetic acid were present during the load. At 3 years, very low biopterin levels were found in serum $(0.4 \mathrm{ng} / \mathrm{ml})$; at this age chromatography of serum $^{1}$ showed only 7,8-dihydrobiopterin to be present. At 5 years, after an oral load which increased the phenylalanine level to $2 \cdot 1 \mathrm{mmol} / 1(34 \cdot 7 \mathrm{mg} / 100$ $\mathrm{ml}$ ) after 2 hours, and to $2 \cdot 8 \mathrm{mmol} / 1(46 \cdot 3 \mathrm{mg} / 100 \mathrm{ml})$ after 4 hours, the initially low biopterin concentration in serum $(0.2 \mathrm{ng} / \mathrm{ml})$ rose to $0.6 \mathrm{ng} / \mathrm{ml}$ at the $3 \mathrm{rd}$ hour and to $0.55 \mathrm{ng} / \mathrm{ml}$ at the 6 th hour. The phenylalanine plasma level was still high $(0.9 \mathrm{mmol} / 1 ; 14.9$ $\mathrm{mg} / 100 \mathrm{ml}) 18$ hours later. During this time the child was unusually sleepy. The parents did not give permission for a needle biopsy.

Both parents had normal fasting phenylalanine plasma levels and their phenylalanine/tyrosine molar ratios were also normal. 